was enlarged by visits to Canada, the United States, Australia, South Africa and Bermuda. For many years he lectured on botany at the Royal Horticultural Society, and he took a great interest in the work of local natural history societies, having been president of the South London Botanical Institute and chair. man of the Botanical Section of the South-Eastern Union of Scientific Societies.

Among Rendle's more important early scientific publications were an enumeration of the Monocotyledons and Gymnosperms collected by Welwitsch in Angola (1899), a revision of the genus Najas (1899), an account of the family Najadaceæ for Engler's "Pflanzenreich" (1901), and an enumeration of the Graminex of China and adjacent areas in Forbes and Hemsley's "Index Floræ Sinensis" (1903). The families on which he worked most were the Gramineæ and Orchidacer, though the wide scope of his studies left him no leisure in which to do monographic work in either. A joint paper with William Fawcett on the Jamaican species of Lepanthes (1904) was followed by the production, in collaboration with Fawcett, of four volumes of their "Flora of Jamaica", the first of which, comprising the orchids, appeared in 1910 and the fourth in 1926. After Fawcett's death, Rendle completed a fifth volume (Rubiacer and Compositæ), the greater part of which had been prepared by Spencer Moore.

Among the wide range of subjects which engaged Rendle's attention were bibliography and nomen. clature. His studies on the flora of Jamaica and the grasses led to the appearance of bibliographical notes on Swartz's "Prodromus" (1897), Steudel's "Synopsis Plantarum Glumacearum" (1899) and Browne's "Natural History of Jamaica" (1912). After Britten's death, he edited the Journal of Botany (1925-38) and the second edition of Britten and Boulger's "Biographical Index of Deceased British and Irish Botanists" (1931).

The world-wide interest in the thorny subject of botanical nomenclature aroused by the publications of Otto Kuntze and other reformers led to the formulation of various proposals for alteration of the Paris "Lois de la Nomenclature botanique" (1867). Those from the British Museum (Natural History) were communicated to the Vienna Congress (1905) by Rendle, who attended the meetings as delegate for the Linnean Society as well as for the Museum Department of Botany. He served as a member of the editorial committee of the International Rules of Botanical Nomenclature in 1905-1935, and was responsible for the English text of the third edition of the Rules.

Rendle became a fellow of the Linnean Society of London in 1888 and served for three periods on the Council before his election as secretary in 1916-23 and president in 1923-27. He regularly attended the Society's meetings, taking part in the discussions and contributing numerous papers to the Journal (Botany) and Transactions. He was elected a fellow of the Royal Society in 1909.

The keynote of Rendle's career was conscientious performance of duty. Whatever came to his hand, he did it.
T. A. S.

\section{Prof. A. V. Martynov}

Andrei Vassilievitch Martynov, whose death occurred on January 28, was born in 1879 in Riazan, Central Russia. After graduating at the University of Moscow, he became an assistant professor in the University of Warsaw, then a zoologist in the Zoological Museum at the Academy of Sciences in Leningrad, and finally professor in the new Institute of Palæontology of the U.S.S.R. Academy of Sciences at Moscow.

The scientific work of Martynov in the earlier period was mainly concerned with the study of the systematics and zoogeography of Trichoptera (caddisflies), in which group he was one of the leading experts and on which he published several first. class monographs and a very large number of papers. This work led him to broader studies in insect morphology, more particularly in investigations of wing venation from an evolutionary point of view, and in this direction he made most important contributions to entomological science. Later, he turned his attention to the study of fossil insects, again with brilliant results (see below). As an indication of his unusual ability and energy, it should be mentioned that he also found time to work on the systematics of the Crustacea (particularly Gammaridæ), on which group he produced several important works.

A characteristic feature of all taxonomic researches by Martynov was his persistent seeking for the better understanding of the problem, with the aid not of morphology alone, but also of the ecology and the distribution of the animals studied. For his researches he was awarded the degree of doctor of biological sciences by the U.S.S.R. Academy, while the Société Entomologique Belge and the Russian Entomological Society elected him an honorary member.

Owing to the extensive circle of his interests, Prof. Martynov, although he had never been abroad, was probably one of the most widely known Russian entomologists, and his premature death will be felt deeply throughout the entomological world.

B. P. Uvarov.

As a palæo-entomologist, A. V. Martynov had an international reputation. His palæontological work was devoted entirely to the fossil insect deposits of Russia, among which those of the Permian of Tikhiye Gory and those of the Jurassic beds of Turkestan (Kara Tau) deserve special mention. From these and many other localities, Martynov described, in about forty publications, a great number of new forms, many of them of considerable phylogenetic importance. In particular, it was his work on the Permian insects which made Martynov widely known and brought him into close contact with the late Dr. R. J. Tillyard, who worked on the Permian insects of Australia and of Kansas, and with Carpenter, who is investigating the Kansas fauna. Before Martynov's studies in fossil insects, almost nothing was known from Russian territory. Now, after his premature death, Russia occupies a prominent place in palæo-entomology, and this is entirely due to Martynov's energy. His qualifications as a 